\title{
Geochemistry and geotechnical models - a case study from the proposed Kempfield Silver Project, Bathurst, New South Wales
}

\author{
H. Baxter Pells Sullivan Meynink, Australia \\ T. Rutherford Pells Sullivan Meynink, Australia \\ R. Bertuzzi Pells Sullivan Meynink, Australia
}

\begin{abstract}
This paper presents a case study on the proposed Kempfield Silver Project where geochemistry was used to define sub-surface fault structure orientation. The Kempfield site is located within the Hill End Trough along the eastern margin of the Lachlan Fold Belt. Surface outcrop is sparse with mapping mostly limited to lithology. However, similarities in the alteration of the lithologies limited their use in correlating faults. Geochemical assays of chip samples were made for over 35 minerals/elements, including aluminium, titanium, potassium, calcium and iron. Using Vulcan to view boreholes in $3 D$, the amounts of each element was assessed for correlations that may define changes in lithology, alteration or the presence of structures. Iron grades (Fe) proved the most favourable for the identification of structures at depth, with a distinct correlation of lithology with $>5 \%$ Fe on the hanging wall of faults and $<5 \%$ on the footwalls. The fault dips indicated by the geochemical assessment were commensurate with fault orientations from oriented core. This information was then factored into the geotechnical model and used as part of the slope stability analysis.
\end{abstract}

\section{$1 \quad$ Introduction}

An understanding of the orientation of major geological structures is fundamental to a geotechnical model. This paper presents a case study from the proposed Kempfield Silver Project where non-traditional techniques were used to increase confidence in the geotechnical model for the site.

The oriented core data available suggested the site was structurally complex however the benign topography of gently rolling hills limited the ability to gather surface mapping data. Airborne geophysics supported the surface understanding, though could provide no further insight as to the dip angle or dip direction. Faults were recognised in the core but uncertainties remained in extrapolating structures to depth.

The site however had significant non-cored drilling data including geochemical assays of over 35 elements. This data was used to assist in delineating the major structures. The hypotheses behind using this data and the results are summarised.

\section{Background and geological history}

\subsection{Project background}

Interest has been expressed in the Kempfield area since the early 1900s, first as a source of alluvial gold then later as a silver and barite mine. From 1971 to 1975 the Geological Survey of NSW undertook detailed mapping and geochemical assessment to assess the extent of mineralised zones. At the same time, International Nickel Australia (Inco) commenced exploration for polymetallic base-metal deposits associated with volcanic rocks, drilling within a single stratigraphic horizon, known as the Mather Zone. From 1979 to 2007, various companies including the Shell Company of Australia, Jones Mining, Plutonic 
Operations and Golden Cross Resources undertook drilling, geochemistry and mapping programs designed to identify and define the available resource.

Argent Minerals acquired the deposit in 2007, undertaking additional drilling and testing as well as a program of airborne and surface geophysical surveys.

\section{$2.2 \quad$ Regional setting}

The Kempfield volcanic hosted massive sulphide (VHMS) silver deposit is located within the eastern province of the Lachlan Fold Belt (LFB), inland of Sydney in New South Wales, Figure 1. The LFB is an orogenic system over $1,000 \mathrm{~km}$ wide that formed along the Pacific margin of Gondwana during the Palaeozoic and can be sub-divided into four structural provinces (Foster et al., 1999).

Kempfield is located in the eastern most province of the LFB. This province is characterised by thick turbidite successions and mafic to felsic lower Ordovician to early Silurian volcanic rocks and considered to be a convergent terrane (Foster et al., 1999). Prolonged crustal extension during the mid-Silurian to Middle Devonian (Collins, 2002) resulted in development of back-arc rift basins including the Hill End Trough with deposition of quartz-rich turbidites, felsic and mafic volcanic rocks, volcaniclastic rocks and black shales, later subjected to greenschist facies metamorphism during the middle to late Devonian (Downes and Seccombe, 2004). VHMS mineralisation occurred in the late Silurian concentrated within the Campbell's (which includes the units observed at Kempfield), Mumbil, Chesleigh and the Tanabutta Groups (Downes and Seccombe, 2004).

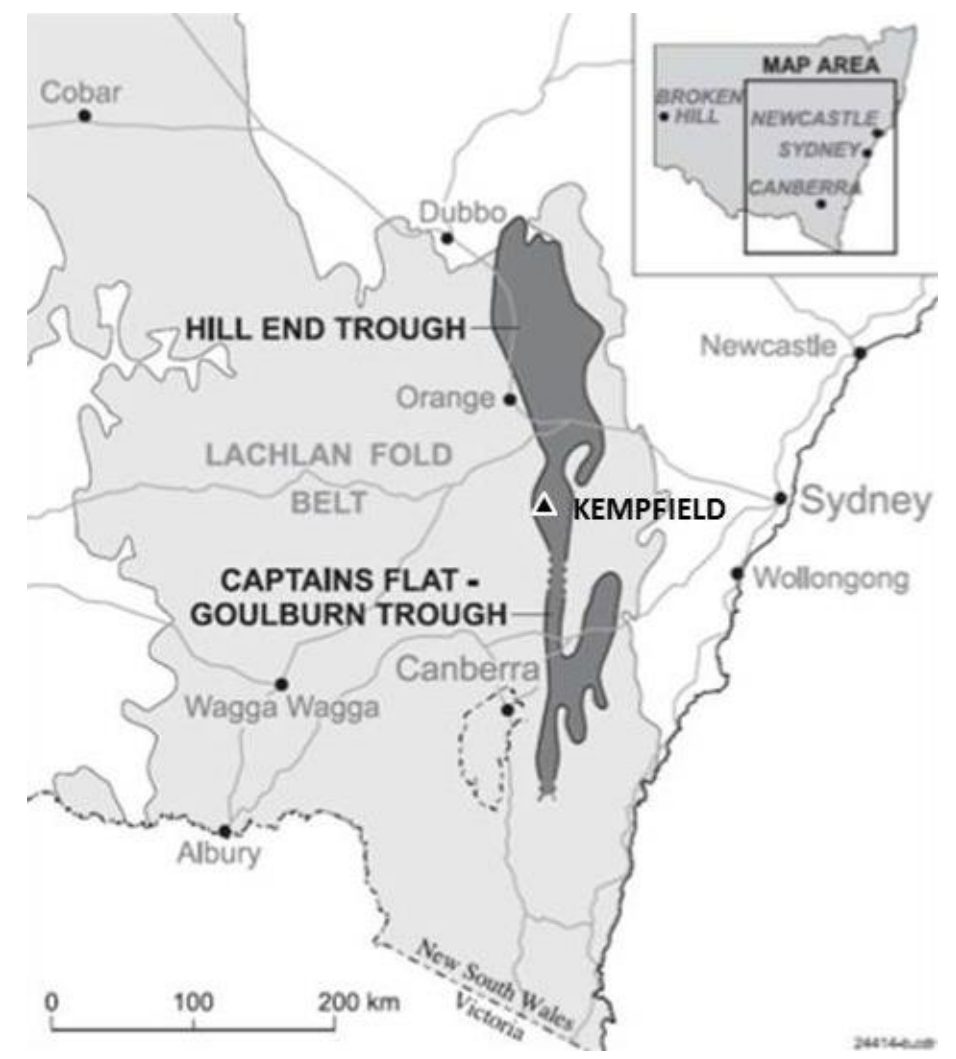

Figure 1 Regional setting (after Downes and Seccombe, 2004)

\subsection{Local geology}

The geomorphology of Kempfield is characterised by a gently undulating topography interspersed with broad shallow valleys. The valleys strike east-west intersecting the major north-south drainage line (mine grid). The site rises in elevation to the north (the Quarries Zone) and is bound to the west by the Molong High, comprising meta-sediments of the Coombing Formation (Wyborn and Henderson, 1997). The eastern margin of the site is defined by the Copperhannia Thrust, Figure 2. 


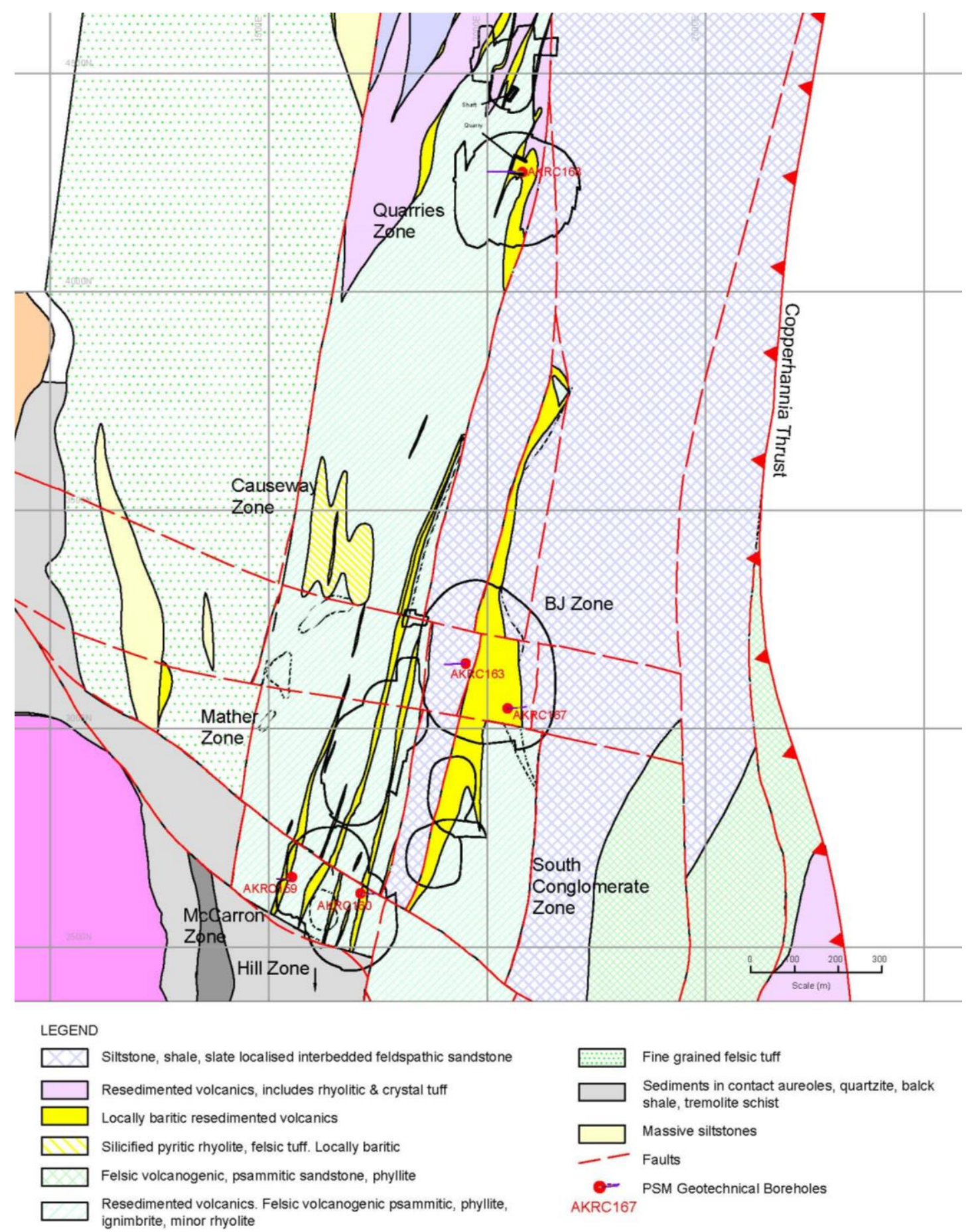

Figure 2 Local geology

The geology comprises Ordovician-aged rocks of the Coombing Formation overlain by late Silurian-aged rocks of the Kangaloolah Volcanics, which is part of the Campbells Group (Wyborn and Henderson, 1997). The Coombing Formation consists tremolite schists, biotite hornfels, porphyritic andesite and black carbonaceous slate (Downs and Seccombe, 2004; Timms and David, 2011). The Kangaloolah Volcanics is locally subdivided into three units (Timms and David, 2011):

1. Fine grained quartz-rich tuffs, faulted against.

2. Volcaniclastic rocks that host silver mineralisation closely associated with barite lenses. The upper part of which comprises limestone/dolomite and massive barite, grading into.

3. Unaltered barren siltstone. 
Mineralisation is confined to north-south striking (mine grid), strata-bound, barite-rich, re-sedimented volcanics. Fault blocks typically confine the mineralised zones, with mineralisation concentrated near to the faulted boundaries between the greenschist facies volcaniclastics and the unaltered siltstones. The occurrence of multiple sub-parallel lenses of barite-rich material has been attributed to deformation and/or the presence of numerous mineralised layers within the original bedrock (Timms and David, 2011).

Two forms of mineralisation are recognised at Kempfield; primary sulphide mineralisation and silver oxide mineralisation associated with barite lenses. The mineralisation appears structurally controlled with seven zones identified, Figure 2:

1. Three primary zones: McCarron, BJ and Quarries.

2. A further four low grade secondary zones: South Conglomerate, Causeway, Mather and Hill.

The structural pattern of the site is controlled by the Copperhania Thrust, an imbricated thrust fault zone generally trending north (mine grid). The Copperhania Thrust is interpreted as a steeply west dipping to sub-vertical fault system with a west-over-east, reverse dip-slip sense of movement. This sense of movement has been attributed to the intrusion of the Sunset Hills Granite to the west of the site (Lennox et al., 2005).

Airborne geophysical surveys and aerial photography commissioned by Argent Minerals were used to infer the location of the Copperhania Thrust and identify sub-parallel deposit-scale faulting, Figure 3 . The aerial data suggests that the north-south faults dip towards the west but at a shallower angle than the main thrust zone. A secondary set of faults was also identified in the aerial data, oriented perpendicular to the dominant north-south set. These faults are inferred to occur at a later stage as they offset the north-south faults.

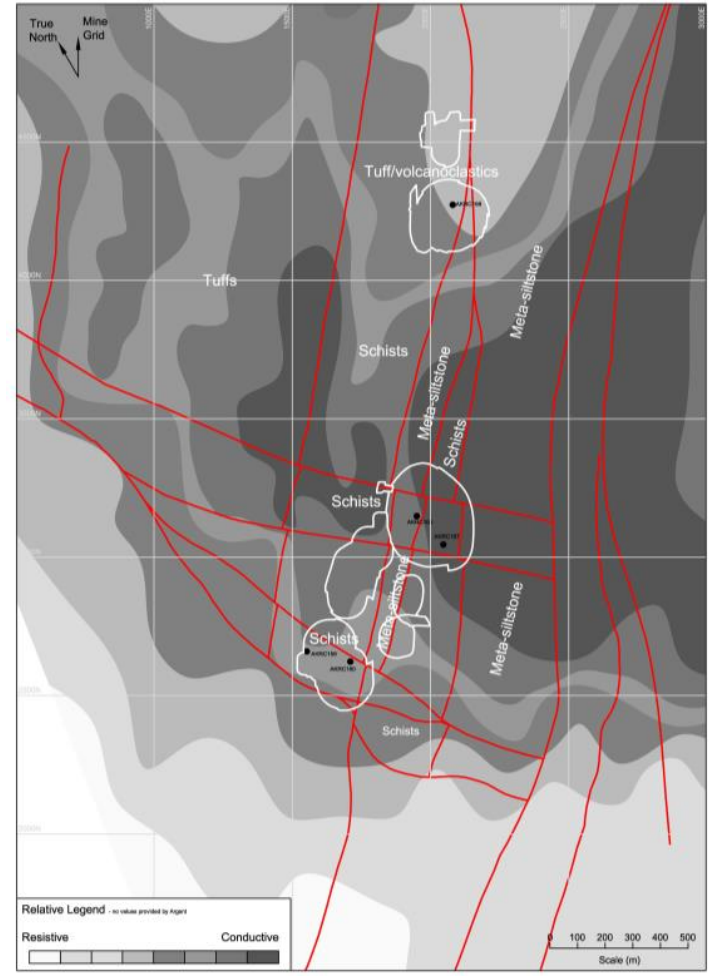

(a)

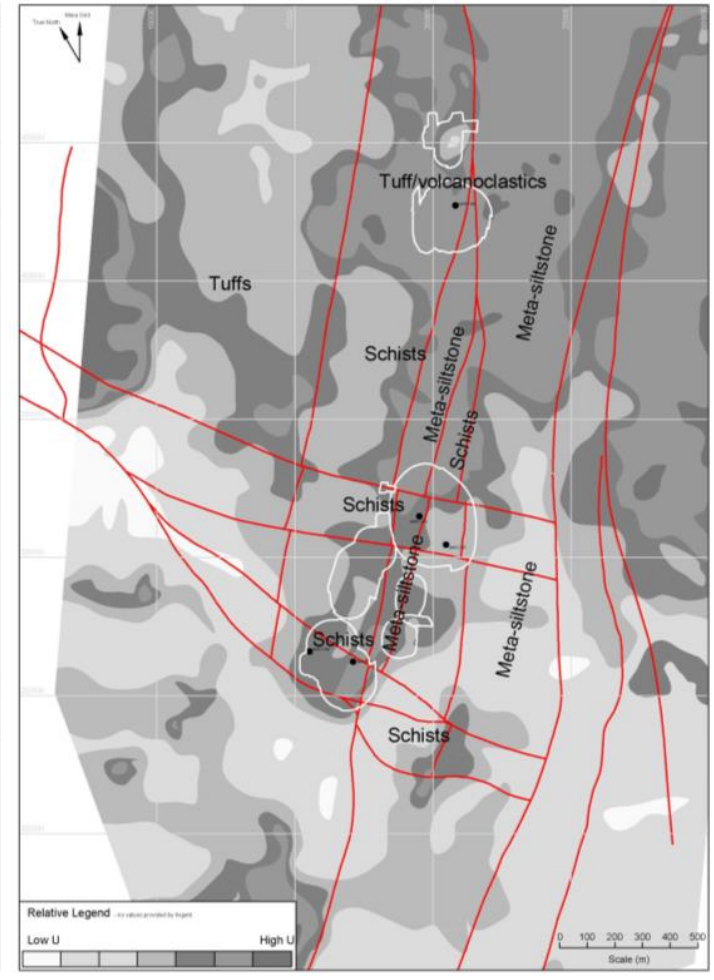

(b)

Figure 3 Geophysical surveys; (a) conductivity survey channel 12B; and (b) uranium count. The red lines show the fault traces inferred from aerial data 


\section{Drilling investigation}

\subsection{Available data}

To date 479 boreholes have been drilled throughout the deposit equating to approximately $40,000 \mathrm{~m}$. Of these boreholes, 67 are diamond cored holes ranging in size from NQ $(47.6 \mathrm{~mm})$ to PQ $(85.0 \mathrm{~mm}) ; 62$ of which were drilled as metallurgical holes for the purpose of resource delineation and assay validation. Five orientated geotechnical diamond boreholes were drilled in 2011 for the preliminary pit slope design. Holes were oriented using the ACE tool system. Core drilling totals approximately $8,000 \mathrm{~m}$. The remaining 412 resource boreholes were drilled using percussion methods (approximately 32,000 m). Data obtained from the resource holes includes chip lithology and geochemical assay results.

\subsection{Geotechnical rock mass conditions inferred from drilling}

The Kempfield site consists of two main lithological groups:

1. Turbidite siltstones, variably logged as siltstone, shale and pelite.

2. Volcanoclastics, variably logged as breccia, volcanic breccia, arenite.

Other lithologies are recognised, and some logging reflects the metamorphic condition rather than parent geology. The variation in lithological logging appears to be more a product of the changes in exploration ownership, and use of different geologists, logging to different guidelines over the years, rather than specific geological changes. As such, correlation of units by lithology proved to be difficult.

Greenschist facies metamorphism and alteration fluids appear to provide the dominant geotechnical influence on the rock masses observed at Kempfield. Three alteration rock mass unit types are recognised, Figure 4(a):

1. Meta-sediments (psammite and phyllite).

2. Talc-sericite schist.

3. Barite-silicic schist.

Identification of the rock mass units is however complicated by a deep weathering profile, Figure 4(b), particularly around the McCarron Zone. As such a fourth rock mass unit was characterised, that of Weathered Schist. 


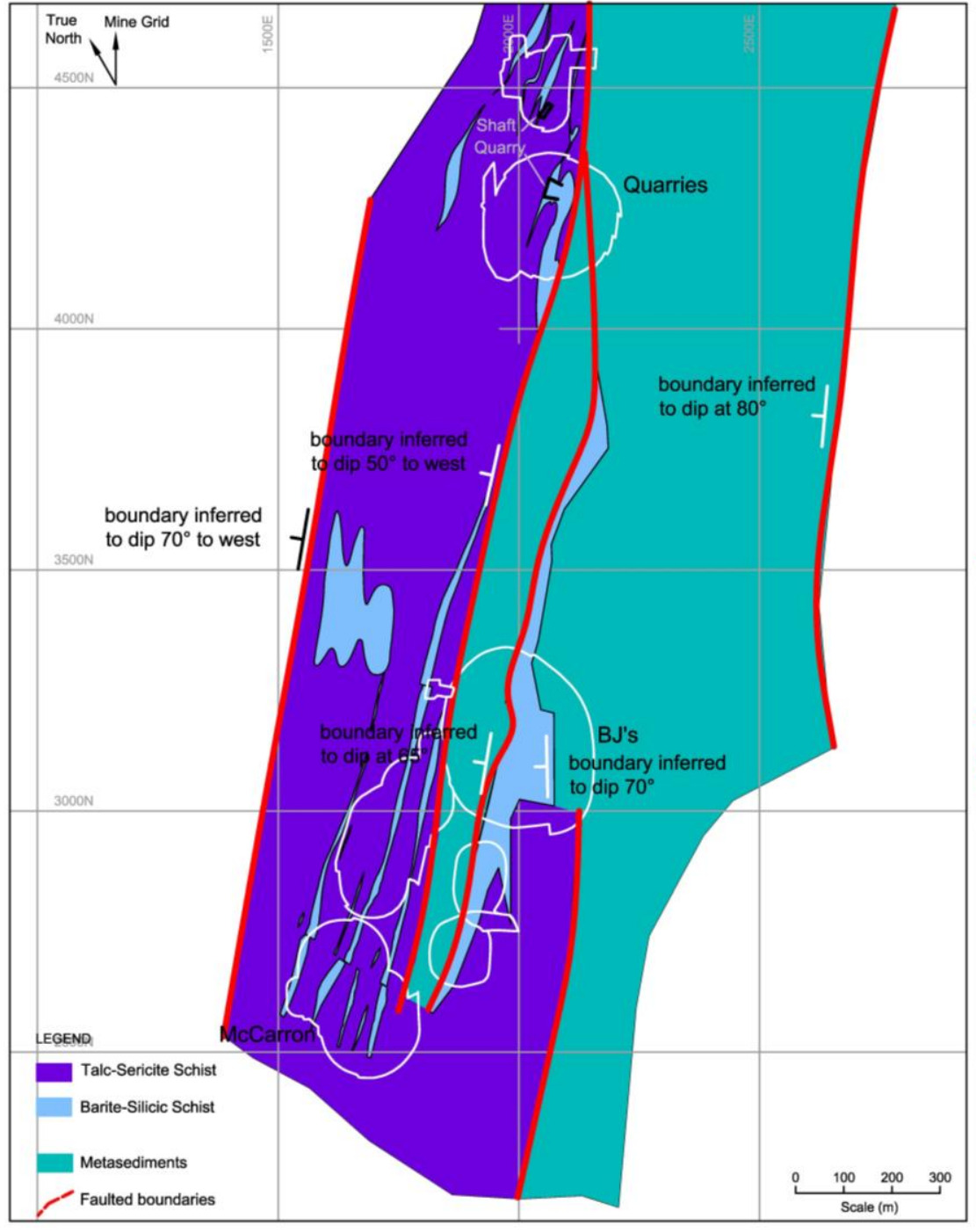

(a)

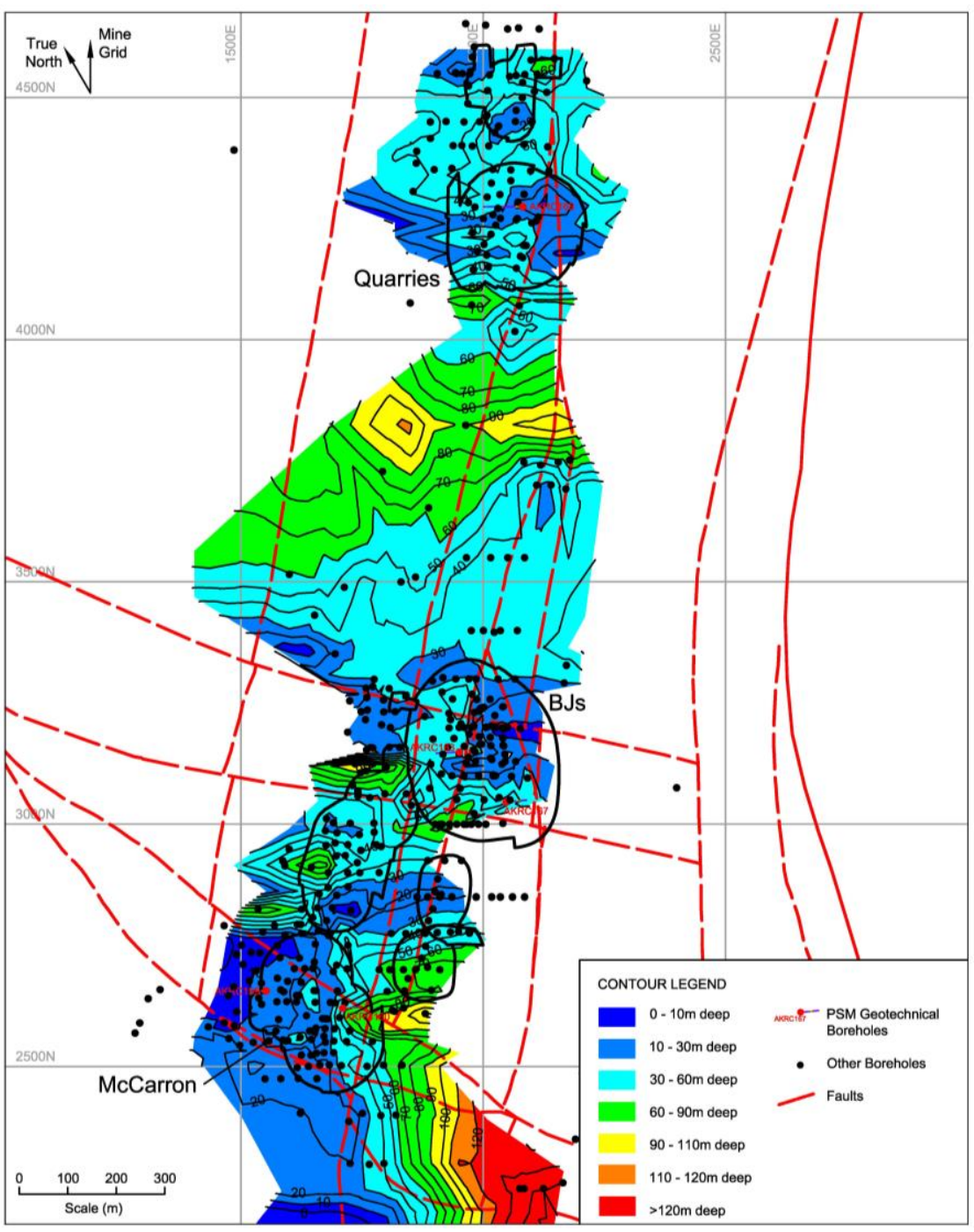

(b)

Figure 4 (a) Distribution of rock mass units; and (b) depth of weathering 
The geotechnical properties of each of the rock mass units based on the Pells Sullivan Meynink (PSM) logging system are presented in Table 1.

Table 1 Geotechnical rock mass units - Kempfield

\begin{tabular}{|c|c|c|c|c|c|}
\hline Rock Mass & Weathering & Alteration & Strength & RQD & Defects \\
\hline Meta-sediments & $\begin{array}{l}\text { Highly } \\
\text { weathered to } \\
\text { fresh, } \\
\text { dominantly } \\
\text { fresh }\end{array}$ & $\begin{array}{l}\text { Unaltered to } \\
\text { altered by } \\
\text { quartz-sericite } \\
\text { and chlorite. } \\
\text { Minor zones of } \\
\text { graphitic }\end{array}$ & Low & $>80 \%$ & $\begin{array}{l}\text { Slightly rough to rough, } \\
\text { with } 1-5 \mathrm{~mm} \text { of rock } \\
\text { fragments and clay }\end{array}$ \\
\hline $\begin{array}{l}\text { Weathered } \\
\text { schist }\end{array}$ & $\begin{array}{l}\text { Highly } \\
\text { weathered }\end{array}$ & $\begin{array}{l}\text { Quartz-sericite and } \\
\text { talc common }\end{array}$ & $\begin{array}{l}\text { Very low } \\
\text { to low } \\
\text { (20\% } \\
\text { recorded } \\
\text { as soil) }\end{array}$ & $\begin{array}{l}>80 \%, \\
\text { but some } \\
\text { zones } \\
<20 \%\end{array}$ & $\begin{array}{l}\text { Slightly rough to rough, } \\
\text { with } 1-50 \mathrm{~mm} \text { of rock } \\
\text { fragments, talc and } \\
\text { clay }\end{array}$ \\
\hline $\begin{array}{l}\text { Talc-sericite } \\
\text { schist }\end{array}$ & Fresh & $\begin{array}{l}\text { Talc-chlorite and } \\
\text { sericite }\end{array}$ & $\begin{array}{l}\text { Low to } \\
\text { moderate }\end{array}$ & $>70 \%$ & $\begin{array}{l}\text { Polished defects } \\
\text { observed. Infill } \\
\text { thickness ranges from } \\
\text { veneer to }>200 \mathrm{~mm} \text { of } \\
\text { mostly rock fragments, } \\
\text { talc, and gouge }\end{array}$ \\
\hline $\begin{array}{l}\text { Barite-silicic } \\
\text { schist }\end{array}$ & $\begin{array}{l}\text { Fresh to slightly } \\
\text { weathered }\end{array}$ & Barite and silicic & $\begin{array}{l}\text { Low to } \\
\text { moderate }\end{array}$ & $>70 \%$ & $\begin{array}{l}\text { Slightly rough to rough, } \\
\text { with } 1-5 \mathrm{~mm} \text { of rock } \\
\text { fragments and clay }\end{array}$ \\
\hline
\end{tabular}

The oriented core data suggests a system of Copperhania Thrust conjugate faults exist, resulting in the formation of grabens, Figure 5.
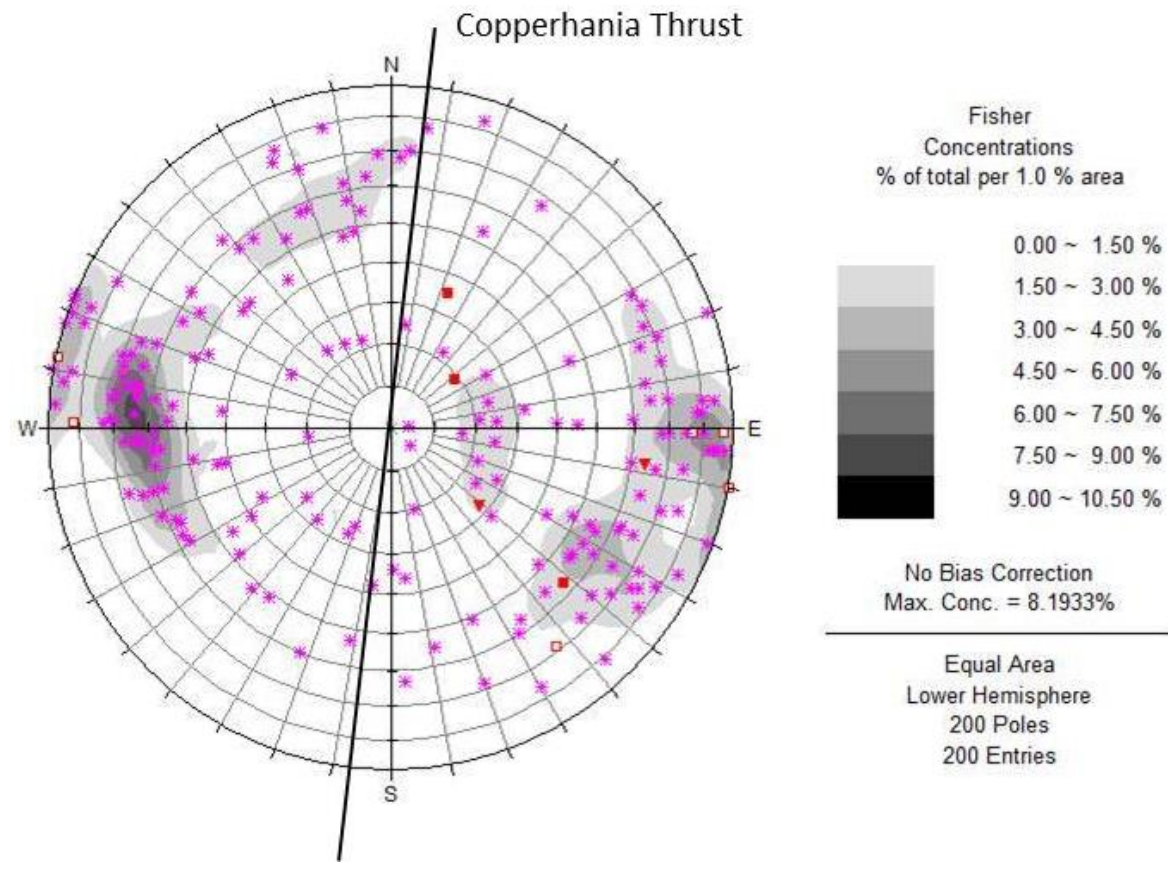

Figure 5 Example stereoplot of oriented core, logged faults and shears, showing Copperhania parallel graben formation mine grid 


\subsection{Gaps in the geotechnical understanding}

The aerial, mapping and drilling data (the 'traditional data'), strongly suggested the Kempfield site is a structurally controlled deposit. While a good understanding of the strike orientation of major lineament structures could be obtained from the 'traditional data' the angle of dip and dip direction and therefore the potential influence on proposed pit slopes was not known. The following sections describe what assessments were undertaken to address this uncertainty and the results.

\section{$4 \quad$ Geochemical assessment}

\subsection{Fault condition}

Observations of core indicated two types of fault material are present at Kempfield:

1. Fault gouge (most common).

2. Mixed breccia and gouge zones (Figure 6).

Occasionally, a weathering halo adjacent to the fault zones was recognised in otherwise unweathered rock.

The scale of the fault zones was typically less than $3 \mathrm{~m}$, with many occurring as discrete structures only a few hundred millimetres thick. The fault zone widths were therefore often less than the assay sample width of two metres. As such, the ability to locate an individual fault gouge structure through geochemical means was remote, unless the clay mineral geochemical signature of the gouge was significantly different to the adjacent bedrock. Additionally, breccia style faults were unlikely to be delineated due to the similarities between the breccia and the surrounding bedrock. However, the weathering halo associated with faulting was considered a possible geochemical signature that could be recognised.
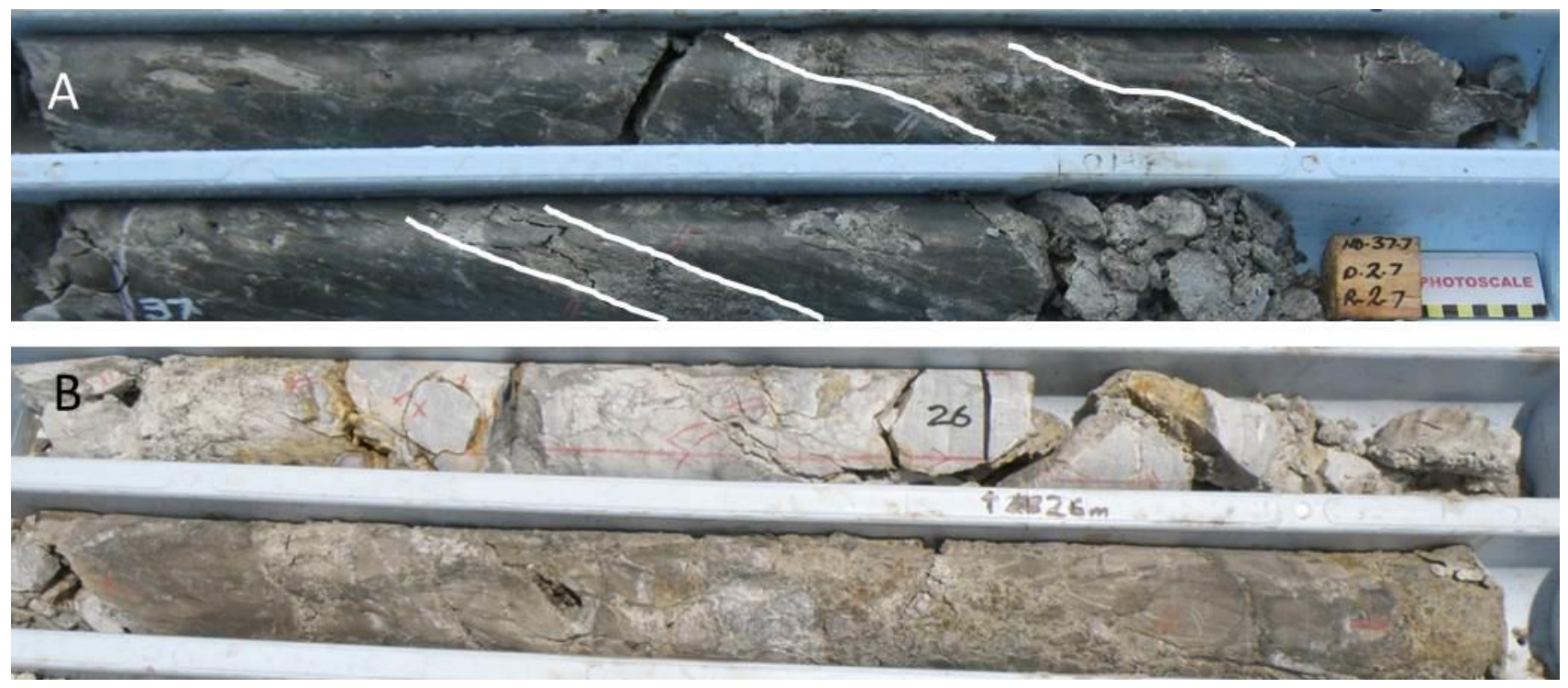

Figure 6 (a) Example of discrete fault gouge structures; and (b) mixed breccia and gouge style faulting. Both examples from borehole AKRC 0159

\subsection{Potential for structure identification}

The style and width of faults zones posed limitations on the potential for identification through geochemistry. Two options were considered:

1. Search for the actual faults themselves anyway, looking for subtle variations in:

a. Clay mineralogy to signify gouge.

b. Fe and Al percentage abundance signifying increased weathering. 
2. Search for bounding structures (no defined width) that separate zones of geochemical contrast that may be attributed to major lithological or alteration/metamorphic grade changes in the bedrock.

The following elements were selected to test if the faults or bounding structures could be recognised:

- Fe and Al for the weathering halo.

- $\mathrm{Al}, \mathrm{K}$, and Ti for gouge.

- Ca for cementation of breccia zones.

The selection of these elements for assessment was based on identification of typical clay minerals and weathering products within the fault zones observed in the core.

Overall, there appeared to be variation in Fe and Al to warrant further study. Fe values proved the most useful in identifying bounding structures with high Fe values $(>5 \%)$ attributed to hanging wall lithologies, Figure 7. $\mathrm{K}$ and Ti value ranges appeared too uniform for any significant variation to be apparent. Ca values showed no clear trends.

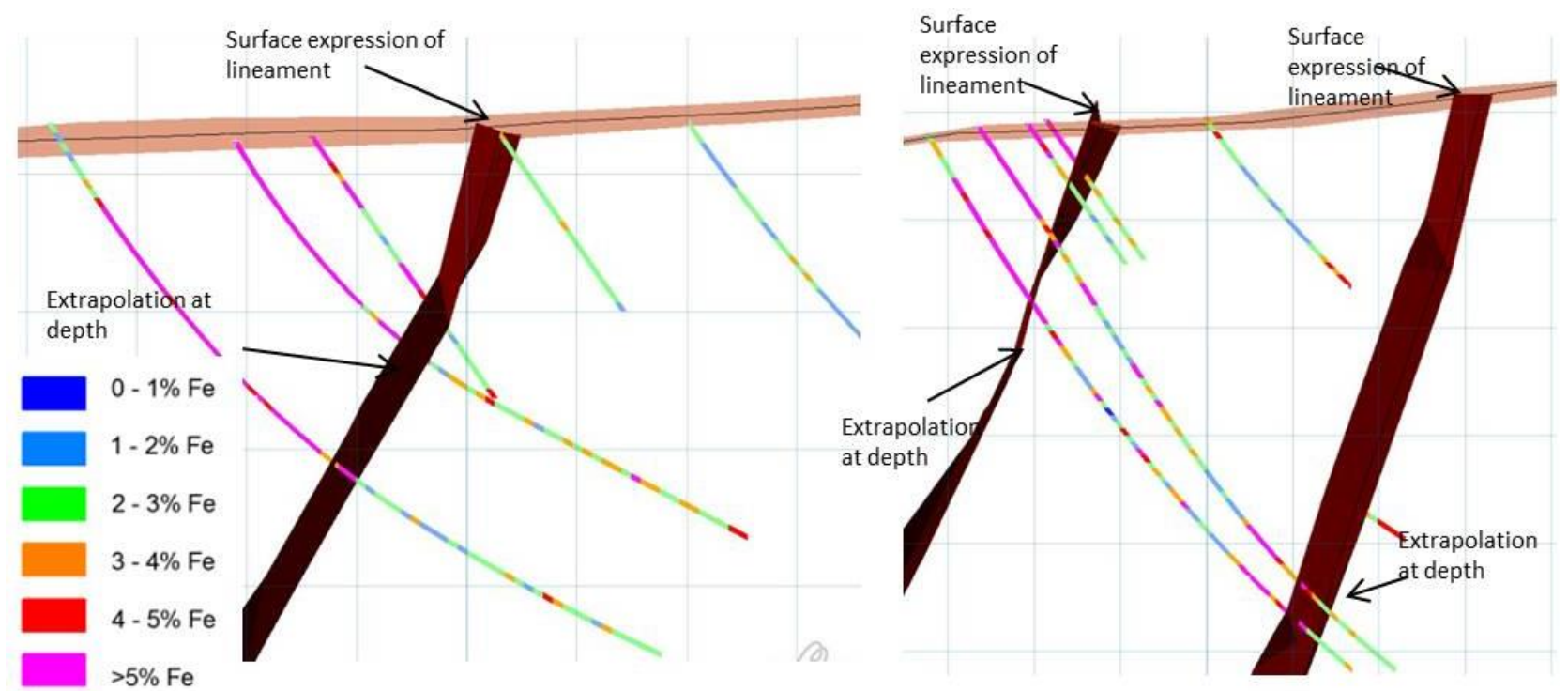

Figure 7 Two example east-west oriented cross-sections showing elevated Fe on the hanging wall of extrapolated faults

\subsection{Results}

Data was loaded as borehole traces in Vulcan. The program allows boreholes and other surfaces to be viewed in 3D, thereby potentially making interpretation and extrapolation between holes simpler.

The pattern of high Fe values in hanging wall lithologies could be observed over large areas, allowing detailed correlation and dip orientation assessment of three major north-south lineaments, Figure 8 , including one not identified from 'traditional data'. 

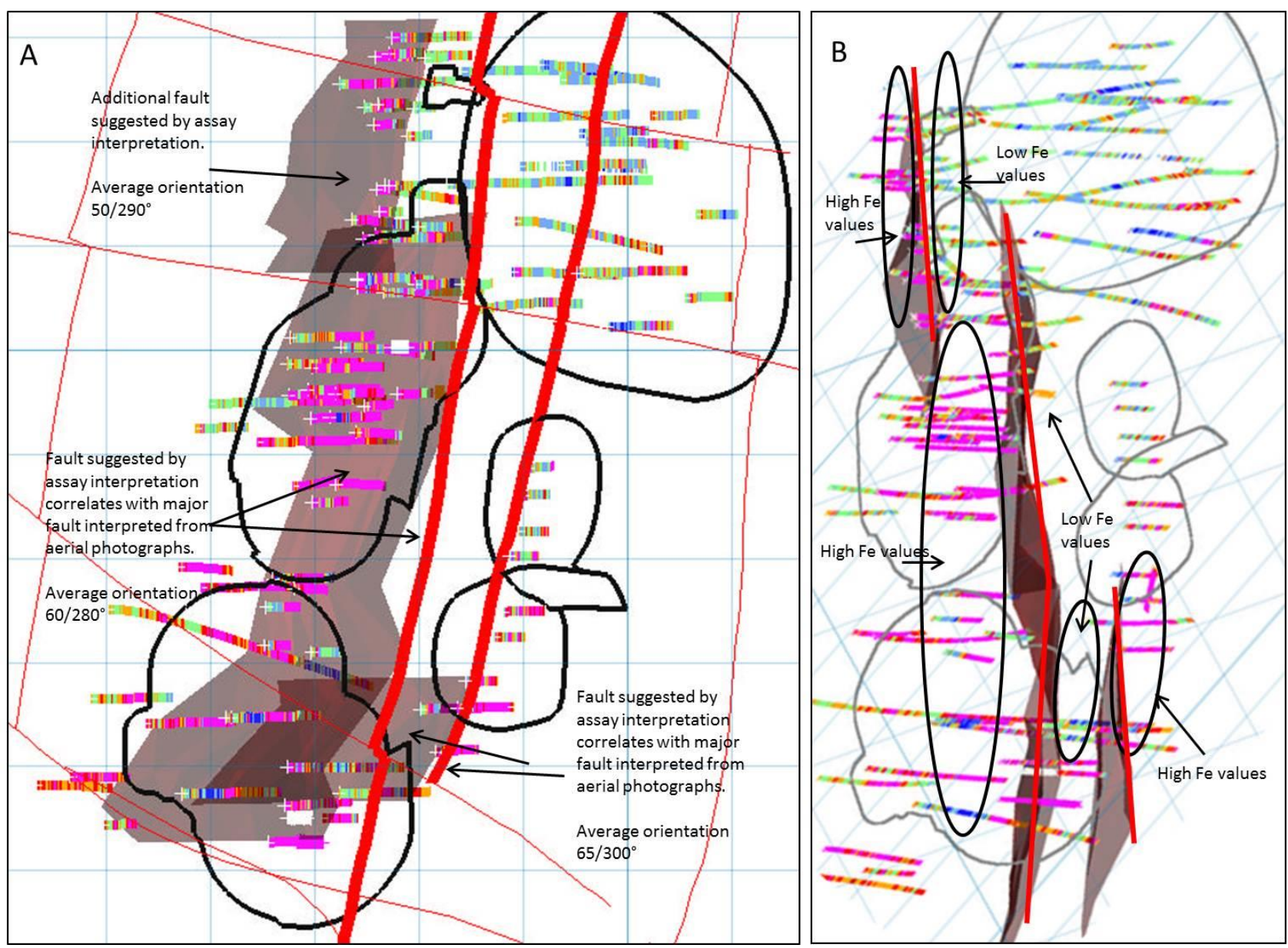

Figure 8 (a) Plan view; and (b) rotated view showing correlation between lineament expression on the surface and borehole Fe values at depth

The dip orientation suggested by the Fe assays was commensurate with the major fault orientation sets indicated from the oriented core data. As such, there was confidence in the extrapolations and improved understanding for the model. Overall using the assay data in conjunction with the oriented core information, the dip and dip direction orientation of most of the major lineaments abounding the proposed pits was assessed (Figure 9). This significantly increased the confidence in the structural model.

\section{Conclusions}

Reviewing the geochemistry data that was collected for resource purposes proved to be a cost-effective means of addressing some of the uncertainties in the geotechnical model. While assay data could not be used in this case to identify specific fault planes, clear boundaries could be identified. These boundaries, coupled with the structural understanding of the area obtained from 'traditional data' allowed better interpretations of the major structure orientations. This increased the confidence in the overall geotechnical model.

Modern tools, such as high-end graphic computers and geological modelling software, allow much greater use of a wider variety of data for geotechnical design.

Geochemistry data, although not widely used for geotechnical modelling, is a valid data source that should be considered when building a geotechnical model especially when there are significant gaps in the available 'traditional data'. 


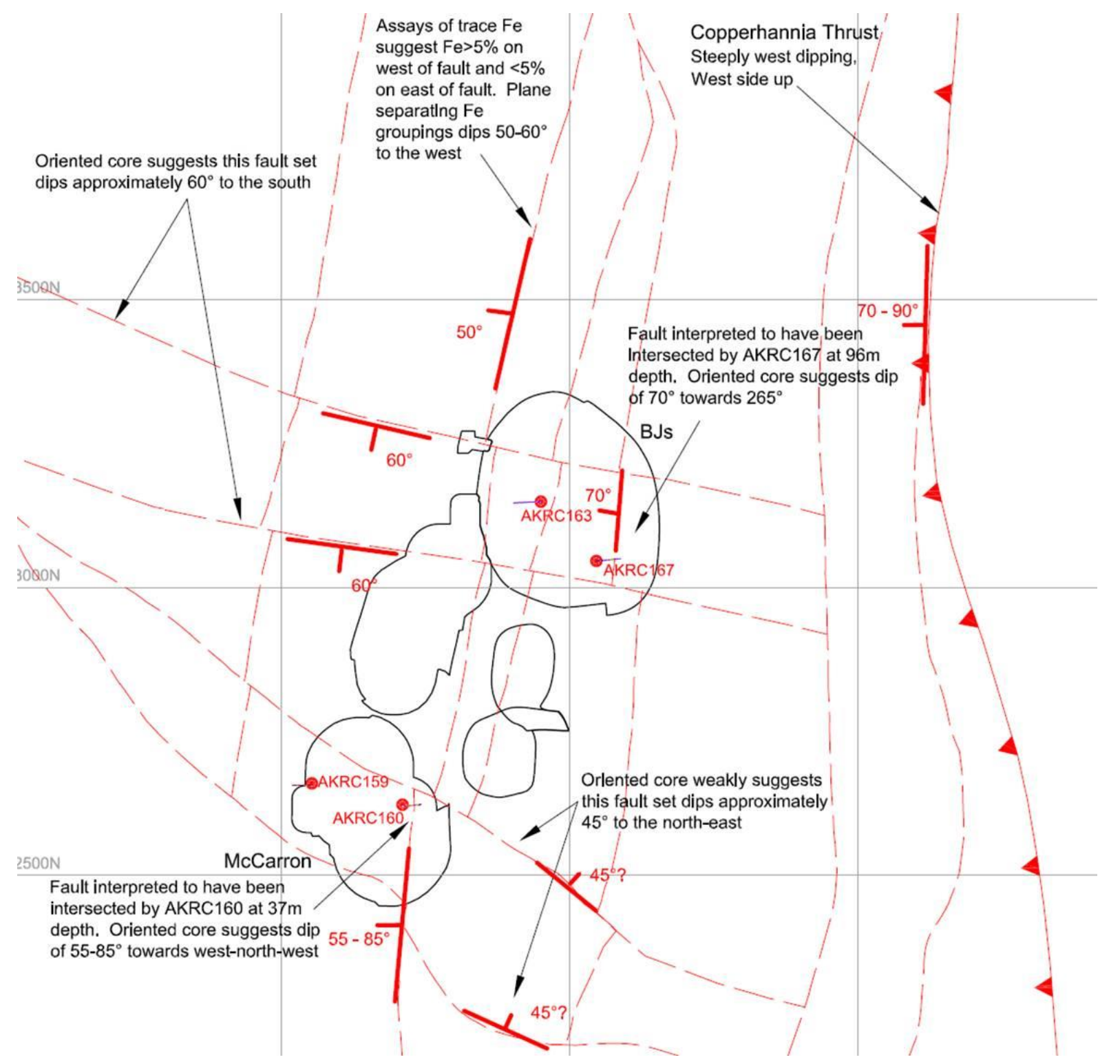

Figure 9 Structural understanding of the Kempfield site following oriented core and assay correlation assessment

\section{Acknowledgement}

We thank Argent Minerals for approval to publish this paper.

\section{References}

Collins, W.J. (2002) Nature of extensional accretionary orogens, Tectonics, American Geophysical Union, Vol. 21(4), pp. 6-1 to 6-12. Downes, P.M. and Seccombe, P.K. (2004) Sulfur isotope distribution in late silurian volcanic-hosted massive sulfide deposits of the Hill End Trough, Eastern Lachlan Fold Belt, New South Wales, Australian Journal of Earth Sciences, Taylor \& Francis, Vol. 51(1), pp. 125-141.

Foster, D.A., Gray, D.R. and Bucher, M. (1999) Chronology of deformation within the turbidite-dominated, Lachlan Orogen: Implications for the tectonic evolution of eastern Australia and Gondwana, Tectonics, American Geophysical Union, Vol. 18(3), pp. 452-485.

Lennox, P.G., Trzebski, R., Armstrong, R. and Siebel, W. (2005) Structural evolution and granite chronology of the central Molong Zone, Eastern Lachlan Fold Belt, Australia, Australian Journal of Earth Sciences, Taylor \& Francis, Vol. 52(1), pp. 79-99.

Timms, D. and David, V. (2011) Kempfield silver, barite and base metal (Pb-Zn) deposit, Lachlan Orogen, Eastern Australia, in Proceedings Eighth International Mining Geology Conference, 22-24 August 2011, Queenstown, New Zealand, Australasian Institute of Mining and Metallurgy, Carlton, pp. 211-224. 

Kempfield Silver Project, Bathurst, New South Wales

Wyborn, D. and Henderson, G.A.M. (1997) Blayney 1:100 000 Geological Sheet 8730, 1st edition, Geological Survey of New South Wales. 